\title{
Chemical Modification of 1-Aminocyclopropane Carboxylic Acid (ACC) Oxidase: Cysteine Mutational Analysis, Characterization, and Bioconjugation with a Nitroxide Spin Label
}

Sybille Tachon, ${ }^{a}$ Eugénie Fournier, ${ }^{a, b}$ Christophe Decroos, ${ }^{a}$ Pascal Mansuelle, ${ }^{,}$Emilien Etienne, Marc Maresca, ${ }^{a}$ Marlène Martinho, ${ }^{b}$ Valérie Belle, ${ }^{*_{\mathrm{b}}}$ Thierry Tron, ${ }^{a}$ A. Jalila Simaan*a

Aix Marseille Univ, CNRS, Centrale Marseille, iSm2, Marseille, France

${ }^{\circ}$ Aix Marseille Univ, CNRS, BIP, Marseille, France

‘ Marseille Protéomique (MaP), IMM, FR 3479, CNRS, Marseille, France

\begin{abstract}
1-AminoCyclopropane Carboxylic acid Oxidase (ACCO) catalyzes the last step of ethylene biosynthesis in plants. Although some sets of structures have been described, there are remaining questions on the active conformation of ACCO and in particular, on the conformation and potential flexibility of the C-terminal part of the enzyme. Several techniques based on the introduction of a probe through chemical modification of amino acid residues have been developed for determining the conformation and dynamics of proteins. Cysteine residues are recognized as convenient targets for selective chemical modification of proteins, thanks to their relatively low abundance in protein sequences and to their well-mastered chemical reactivity. ACCO have generally 3 or 4 cysteine residues in their sequences. By a combination of approaches including directed mutagenesis, activity screening on cell extracts, biophysical and biochemical characterization of purified enzymes, we evaluated the effect of native cysteine replacement and that of insertion of cysteines on the $\mathrm{C}$-terminal part in tomato ACCO.
\end{abstract}


Moreover, we have chosen to use paramagnetic labels targeting cysteine residues to monitor potential conformational changes by Electron Paramagnetic Resonance (EPR). Given the level of conservation of the cysteines in ACCO from different plants, this work provides an essential basis for the use of cysteine as probe-anchoring residues.

Index entries: ACC Oxidase, ethylene, iron, cysteine, mutagenesis, protein chemical modification, nitroxide, EPR 


\section{Introduction}

Ethylene is a hormone that controls many developmental and defense processes in plants, including fruit maturation.[1] The last step of ethylene biosynthesis is catalyzed by the nonheme iron containing 1-aminocyclopropane carboxylic acid (ACC) oxidase (ACCO) [2-4] via the oxidation of ACC in the presence of dioxygen and ascorbate. The products of the reaction are ethylene and cyanoformate (which is further converted into $\mathrm{HCN}$ and $\mathrm{CO}_{2}$ ).[5] In addition, ACCO requires the presence of carbon dioxide (or bicarbonate ions) for activity. The reaction catalyzed by ACCO is displayed in Scheme 1.

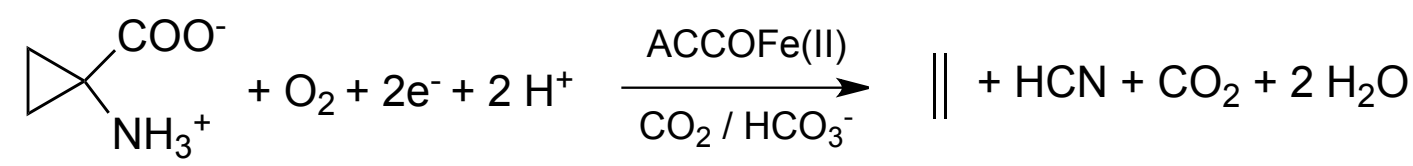

Scheme 1. Reaction of the last step of ethylene biosynthesis catalyzed by ACCO

ACCO is a complex enzymatic system that requires many substrates and cofactors to function and undergoes catalytic inactivation pathways.[6, 7] Consequently, its mode of action is still not well understood and its catalytic mechanism is currently under debate.[3]

ACCO are typically mononuclear enzymes of ca. 310-325 aminoacids. Only two crystal structures of ACCO have been reported so far. The first structure obtained for Petunia hybrida ACCO (PhACO1) revealed a core folded in Double-Stranded- $\beta$-helix (DSBH) or $\beta$-barrel, surrounded by $\alpha$-helices (Figure 1).[8] Although active as a monomer, PhACO1 has been crystallized as a homotetramer with the C-terminal part directed away from the active site and interlocking with the C-terminal part of an adjacent monomer by means of both hydrophobic and electrostatic interactions. Very recently, a set of new structures of Arabidopsis thaliana ACCO (AtACO2) has been reported and the enzyme has been found monomeric in all 
crystals.[9] Besides an extended $\alpha-3$ helix that adopts a differently curved conformation in the case of AtACO2, the main difference between the two structures lies in the C-terminal part that is either directed apart (PhACO1) or towards (AtACO2) the active site. Finally, structural models of ACCO have been constructed with the C-terminal part folded close to the active site in a "closed" conformation that is different from the one seen in the two crystallographic structures.[10, 11] These structural differences might reflect a flexibility of the C-terminus possibly important for the activity of ACCO enzymes.
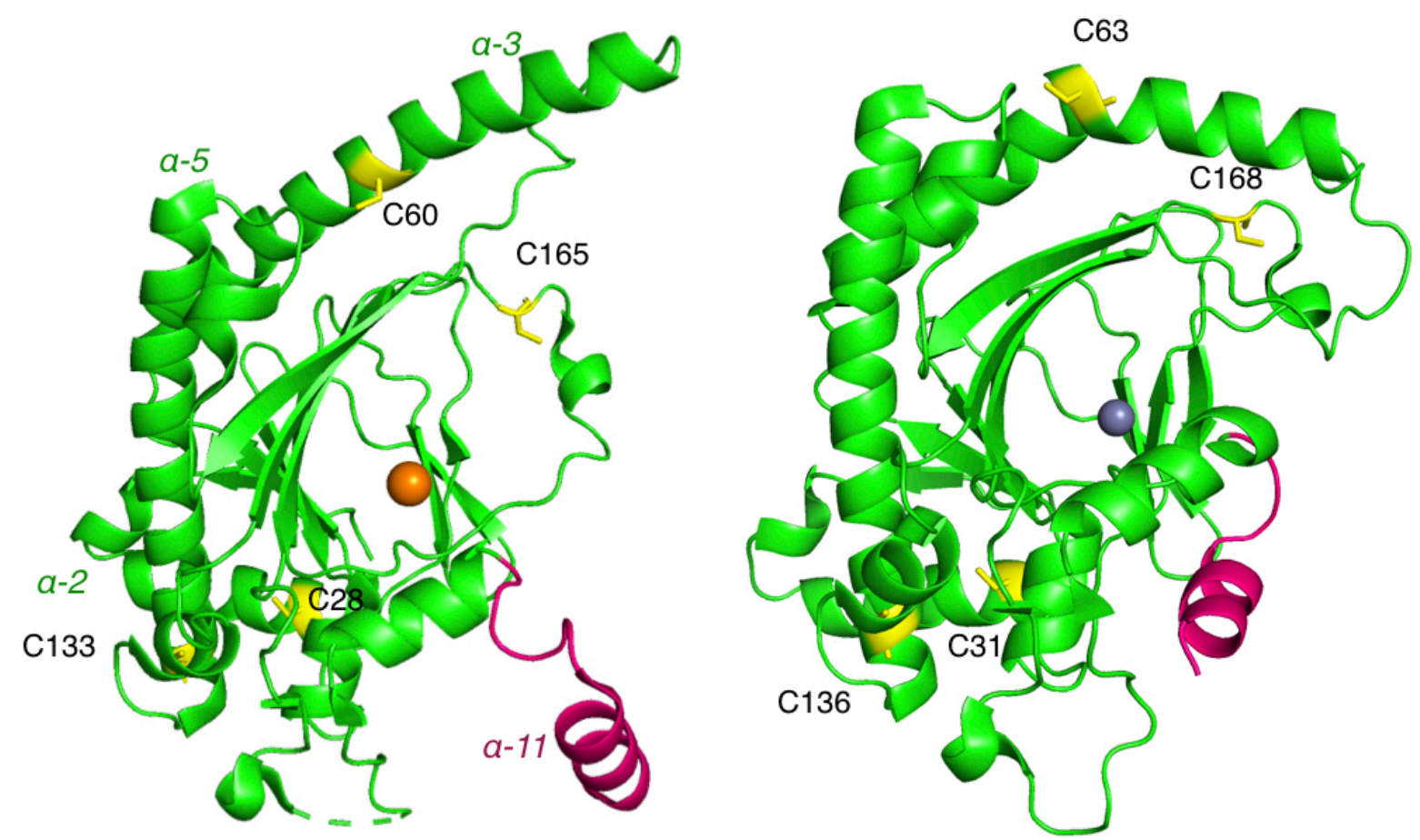

Figure 1. Crystal structures of ACCO (Left) from P. hybrida PhACO1 (pdb 1wa6) and (Right) from A. thaliana AtACO2 (pdb 5gj9) highlighting the C-terminal part after residue 290 (pink), the active site metal ion (orange sphere for iron and grey for zinc) and the cysteine residues (yellow).

Knowledge on the active conformation and a possible flexibility of the C-terminal part would be highly valuable to further understand this enzymatic system. Ideally, such structural information should be obtained under conditions reflecting as much as possible the physiological ones. Techniques for monitoring structures and conformational changes of 
proteins, including in cell or in vivo, are continuously being developed in order to understand protein function, that is often linked to protein dynamics.[12-16] In many cases, these techniques rely on the introduction of a probe (chromophore, fluorophore, magnetic probes etc.) on the protein through chemical modification of specific amino acid residues.[17, 18] In particular, among these techniques, Site-directed Spin Labeling coupled to Electron Paramagnetic Resonance spectroscopy (SDSL-EPR) has emerged as an efficient methodology to monitor protein structure and dynamics. [13, 19-23]

In the recent years, numerous chemical reactions have been developed to achieve selective conjugation under mild conditions to maintain protein structure and function.[24-27] Many of these reactions were developed to target nucleophilic amino acids such as cysteine (C) or lysine (K) residues.[28] However, proteins can contain several native accessible cysteines or lysines, a situation that is not optimal for selective bioconjugation. Therefore, chemical modification techniques often imply, as a first crucial step, the generation of a protein displaying unique and appropriate modification sites while retaining its primary structure and function. ACCO from tomato (Solanum lycopersicum SlACO1 or pTom13)[29] contains four cysteines (C28, C60, $\mathrm{C} 133$ and $\mathrm{C} 165)$ that are neither involved in disulfide bridges nor located close to the active site (Figure 1). Given the fact that ACCO contains a high number of lysine residues (27 lysines in SlACO1 sequence), cysteines appear as the most appropriate targets for bioconjugation. This strategy nevertheless implies reducing the number of available cysteines in view of subsequent chemical modifications. In the present work, we aimed at both studying in depth the effect of cysteine mutation on the functional parameters of the enzyme and evaluating the effect of chemical modification at various cysteines using a paramagnetic label to get information from EPR spectroscopy. For this, we have systematically replaced each of the four native cysteines by other residues and introduced cysteine residues at different positions of the C-terminal part 
of the enzyme. We also generated several C-terminal truncated enzymes to determine the extent of important residues on this C-terminal region. Bioconjugation of selected variants using a stable nitroxide radical (3-Maleimido-2,2,5,5-tetramethyl-1-pyrrolidinyloxy or Proxyl (P)) was performed and monitored by EPR spectroscopy. The labeling sites were confirmed by Mass Spectrometry (MS) and the labeled enzymes were characterized using biochemical and biophysical techniques.

\section{Experimental section}

Unless otherwise noted, all chemicals and solvents were of analytical grade and used without further purification.

2.1. Protein sequence, structure visualization and analysis.

Protein sequences were retrieved from the publicly available databases KEGG (Kyoto Encyclopedia of Genes and Genomes, http://www.genome.jp/kegg/), the NCBI (National Center for Biotechnology Information, https://www.ncbi.nlm.nih.gov/), UniProtKB (Swiss Prot, http://www.uniprot.org/uniprot/) and PDB (RCSB protein data bank, http://www.rcsb.org/pdb/home/home.do). Orthologs and paralogs of the tomato ACCO (Entry: 544052, Organism: Solanum lycopersicum) were identified with KEGG. Sequences were aligned using Clustal W algorithm in the opensource sequence analysis tool BioEdit (T. Hall, Ibis Biosciences). Conservation of the amino acid residues was visualized using BioEdit tools. Protein structure observation and analysis were performed in PDB viewer (http://spdbv.vitalit.ch/).

2.2. Genetic manipulations 
ACCO variants were constructed from a previously published original plasmid based on the pET21a (Novagen) containing the gene encoding the tomato ACCO (pTOM13 or P05116) [29, 30] under the control of the IPTG-inducible T7 promotor. Site-directed mutations of the ACCO encoding gene were performed by PCR using the primers listed in Supporting Information (Table S1 \& Table S2). PCR reactions were performed in $50 \mu \mathrm{L}$ containing 1 unit Phusion DNA polymerase (Thermo Fisher Scientific), 1x Phusion DNA polymerase buffer, $200 \mu \mathrm{M} \mathrm{dNTP}$, $0.15 \mu \mathrm{M}$ each primer, and 10 to $50 \mathrm{ng}$ of template plasmid DNA. The temperature cycles were controlled using a Master Cycler gradient (Eppendorf) thermocycler as follows: 30 seconds at $98^{\circ} \mathrm{C}$ for the initial denaturation, 16 cycles of 30 seconds at $98^{\circ} \mathrm{C}, 1 \mathrm{~min}$ at $55^{\circ} \mathrm{C}, 5 \mathrm{~min}$ at $72^{\circ} \mathrm{C}$, and then $5 \mathrm{~min}$ at $72^{\circ} \mathrm{C}$ for the final extension. $1 \mu \mathrm{L}$ (10 units) DpnI (Thermo Fisher Scientific) was added to PCR products (to digest DNA template) and incubated $1 \mathrm{~h}$ at $37^{\circ} \mathrm{C}$, followed by a 20 min-inactivation step at $80^{\circ} \mathrm{C}$. Digested PCR products were transformed in thermocompetent DH5-alpha E. coli cells. Positive clones were selected according to their resistance to ampicillin on LB-Agar plates containing $100 \mu \mathrm{g} / \mathrm{mL}$ ampicillin (LB-Agar-Amp) and cultured in $5 \mathrm{~mL} \mathrm{LB}$-broth containing $100 \mu \mathrm{g} / \mathrm{mL}$ ampicillin (LB-Amp) at $37^{\circ} \mathrm{C}$ on a wheel overnight. Extraction of the plasmids were performed from the $5 \mathrm{~mL}$ cultures using the QIAprep ${ }^{\circledR}$ Miniprep kit (QIAGEN), according to the manufacturer protocol, with $50 \mu \mathrm{L}$ elution in water. Concentrations were determined with a Nanodrop 2000c (Thermo Scientific) and sequences were controlled by Sanger sequencing (Genewiz, UK).

\subsection{Enzymes recombinant expression}

Plasmids containing the gene encoding ACCO and variants were transformed into thermocompetent BL21(DE3) E. coli cells. Transformants were selected on LB-Agar plates containing $100 \mu \mathrm{g} / \mathrm{mL}$ of ampicillin. 
For screening purposes: transformants were subcultured in $600 \mu \mathrm{L} \mathrm{LB}-\mathrm{Amp}$ at $37^{\circ} \mathrm{C}$ in 96 -well DeepWell plates shaken overnight at $200 \mathrm{rpm}$. Cells were diluted at 1/30 and placed in $1 \mathrm{~mL}$ LB-Amp medium in 96-well DeepWell plates and incubated $1 \mathrm{~h} 30$ at $37^{\circ} \mathrm{C}$ under $200 \mathrm{rpm}$. ACCO expression was induced by IPTG addition to a final concentration of $0.5 \mathrm{mM}$ and further incubation at $37^{\circ} \mathrm{C}$ during 3 hours and under $200 \mathrm{rpm} .300 \mu \mathrm{L}$ of the culture were saved for ACCO quantification by ELISA assays. Remaining cells were harvested in 96-well plates by centrifugation $\left(3500 \mathrm{rpm}, 10 \mathrm{~min}, 4^{\circ} \mathrm{C}\right)$ and cells pellets were frozen at $-20^{\circ} \mathrm{C}$. The cultures were split into two parts. One part was used for ELISA assays to quantify ACCO in E. coli cells; the second part was used for ACCO activity determination.

For scale-up production: the protocol was adapted from already described procedures.[8, 11, 31] Transformants were subcultured in LB-Amp at $37^{\circ} \mathrm{C} 200 \mathrm{rpm}$ to reach an Optical Density at $600 \mathrm{~nm}\left(\mathrm{OD}_{600}\right)$ of 0.5 , before being diluted at $\mathrm{OD}_{60}=0.05$ in $200 \mathrm{~mL}$ or $2 \mathrm{~L}$ Terrific Broth (TB) containing $100 \mu \mathrm{g} / \mathrm{mL}$ ampicillin (TB-Amp) and incubated at $37^{\circ} \mathrm{C} 200 \mathrm{rpm}$ until reaching $\mathrm{OD}_{60}=1$. The culture was then placed at $28^{\circ} \mathrm{C}$ during $40 \mathrm{~min}$, and the expression was induced by IPTG addition to a final concentration of $0.5 \mathrm{mM}$. The culture was further incubated at $28^{\circ} \mathrm{C}$ $200 \mathrm{rpm}$ during 3 hours. Cells were then harvested by centrifugation $20 \mathrm{~min}$ at $8000 \mathrm{rpm}$ (13800 g) at $4^{\circ} \mathrm{C}$ and conserved at $-20^{\circ} \mathrm{C}$.

\subsection{Enzyme purification}

All purification steps were performed at $4^{\circ} \mathrm{C}$ and following a procedure adapted from previously reported protocols.[11, 32] Thawed cell pellets were resuspended in lysis buffer containing 1x BugBuster (Merck Millipore), $10 \%$ glycerol, 3 mM EDTA, 5 mM dithiothreitol (DTT) and $1 \mathrm{mM}$ benzamidine and were incubated $20 \mathrm{~min}$ at $4^{\circ} \mathrm{C}$ under gentle stirring $(25 \mathrm{rpm})$. Cells debris were removed by centrifugation at $18000 \mathrm{~g}$ for $45 \mathrm{~min}$ (Sorvall Lynx 6000, Thermo 
Scientific). The supernatant was dialyzed in dialysis tubing (Spectra/Por, Spectrumlabs) of 1214 kD MWCO against buffer A (25 mM HEPES pH 8.0, $10 \%$ glycerol, 3 mM EDTA, 1 mM benzamidine) and loaded on a Ion Exchange resin (Fast Flow Q Sepharose ${ }^{\mathrm{rm}}$, GE Healthcare), equilibrated with buffer A. Purification was performed using the Akta Purifier FPLC System (GE Healthcare). ACCO was eluted with buffer B $(\mathrm{A}+150 \mathrm{mM} \mathrm{NaCl}) . \mathrm{NaCl}$ and EDTA were removed by dialysis against $25 \mathrm{mM}$ HEPES pH 7.2, $10 \%$ glycerol and the proteins were frozen until further analysis. ACCO was $c a .95 \%$ pure according to sodium dodecyl sulfate polyacrylamide gel electrophoresis (SDS-PAGE) analysis.

\subsection{ELISA assays}

The amount of ACCO protein in BL21 cell lysates was determined by enzyme-linked immunosorbent assay (ELISA) using a rabbit anti serum directed against ACCO and a goat anti-rabbit antibody for detection. HRP activity was used for quantitation. ACCO was quantified by extrapolating the signal into a linear range (signal $v s$ concentration) of a standard curve realized with «naive » BL21 suspension cells supplemented with known amounts of ACCO ranging from $0.6 \mathrm{ng} / \mu \mathrm{L}$ to $6.25 \mathrm{pg} / \mu \mathrm{L}$. Cell lysates (cells from $300 \mu \mathrm{L}$ culture $+1 \mathrm{x}$ BugBuster $10 \%$ glycerol $3 \mathrm{mM}$ EDTA, $5 \mathrm{mM}$ dithiothreitol and $1 \mathrm{mM}$ benzamidine) were diluted 5000 times in water, deposited in MaxiSorp plates with 9 volumes of coating buffer (15 $\mathrm{mM} \mathrm{Na} \mathrm{CO}_{3}, 85 \mathrm{mM} \mathrm{NaHCO}_{3}$ ) and incubated at $4^{\circ} \mathrm{C}$ overnight. The wells were then washed three times with PBS-0.05\%Tween 20 and saturated with PBS-2\%BSA 1 hour at room temperature. PBS-2\%BSA 1/10000 dilution of Rabbit-anti-ACCO antibody was added before incubation 1 hour at room temperature. The wells were then washed three times with PBS$0.05 \%$ Tween 20 and PBS-2\%BSA 1/10000 dilution of HRP conjugate Goat-anti-Rabbit antibody was added before incubation 1 hour at room temperature. After three more washing steps with PBS-0.05\% Tween 20, the HRP substrate (Sigmafast OPD, Sigma) was added. After 
incubation in the dark for $30 \mathrm{~min}$ at room temperature, the reaction was stopped with $\mathrm{H}_{2} \mathrm{SO}_{4}$ and appearance of coloration was measured at $490 \mathrm{~nm}$ in a plate reader (Synergy Mx, BioTek).

\subsection{Activity assay}

Activity was assayed by detection of ethylene gas by Gas Chromatography (GC). Measurements were performed using a Shimadzu GC-2014A gas chromatograph equipped with a Porapak Q 80/100 column (0.125 in.) and a flame ionization detector (FID). The following conditions were used: $\mathrm{N}_{2}$ carrier gas, $\mathrm{T}_{\text {injector }}=250{ }^{\circ} \mathrm{C}, \mathrm{T}_{\text {oven }}=100{ }^{\circ} \mathrm{C}, \mathrm{T}_{\text {deccector }}=250{ }^{\circ} \mathrm{C}$. Ethylene was quantified versus an external standard (1 \% ethylene in nitrogen, Scott Mini-Mix, Air Liquide). Standard assays were performed at $29{ }^{\circ} \mathrm{C}$ in $1.7-\mathrm{mL}$ hermetically sealed vials using either purified proteins (5 $\mu \mathrm{g}$ of proteins) or resuspended cell pellets in $25 \mathrm{mM}$ HEPES buffer containing $10 \%$ glycerol set at $\mathrm{pH}$ 7.2. The total assay volume was $200 \mu \mathrm{L}$.

For the quantification of the activity, the cofactors and substrates were added at the following concentrations: $18 \mathrm{mM} \mathrm{NaHCO} 3,8 \mathrm{mM} \mathrm{L}$-ascorbic acid, $40 \mu \mathrm{M} \mathrm{Fe}\left(\mathrm{SO}_{4}\right)_{2}\left(\mathrm{NH}_{4}\right)_{2} \cdot 6 \mathrm{H}_{2} \mathrm{O}$ and 1.25 $\mathrm{mM}$ ACC. After $7 \mathrm{~min}$ or $30 \mathrm{~min}$ of reaction for the purified ACCO or the cell extracts respectively, $1 \mathrm{~mL}$ of the headspace gas was removed using a gastight syringe and injected in GC. For the determination of the kinetic parameters, the concentration of one substrate/cofactor was varied while maintaining the others at the following concentrations: $18 \mathrm{mM} \mathrm{NaHCO}_{3}, 8$ $\mathrm{mM}$ L-ascorbic acid, $40 \mu \mathrm{M}$ Fe(II) and $1.25 \mathrm{mM}$ ACC). Variation ranges were $0-2.5 \mathrm{mM}$ for ACC, $0-12 \mathrm{mM}$ for ascorbate and 0-24 $\mathrm{mM}$ for $\mathrm{NaHCO}_{3}$. Each measurement was repeated at least 3 times. Non-linear curve fitting to the Michaelis-Menten equation (eq. 1) were performed using GraphPad Prism 6.0 to determine apparent kinetic constants.

(Eq. 1) $\quad v=\frac{V_{\max }[S]}{K_{M}+[S]}$ 
Where $v$ is the initial velocity, $\mathrm{V}_{\max }$ and $\mathrm{K}_{\mathrm{m}}$ the Michaelis Menten parameters and [S] the substrate's or cofactor's concentration.

\subsection{Thermal Shift Assay (TSA).}

A typical experiment involved incubation of purified native ACCO or variants with SYPRO Orange dye in a 96-well PCR plate. The effect of temperature increments on the structure of the target protein was monitored as function of the increase of the fluorescence of the dye as it binds to the hydrophobic regions of the denatured proteins allowing determination of the melting temperature $(\mathrm{Tm})$.

Protein melting temperatures (Tm) were determined using SYPRO Orange (Roche) as fluorophore. Purified ACCO $(5 \mu \mathrm{M})$ in $25 \mathrm{mM}$ HEPES pH $7.210 \%$ glycerol containing $5 \mathrm{x}$ SYPRO orange was submitted to a temperature gradient from 20 to $95^{\circ} \mathrm{C}$ at a rate of $1{ }^{\circ} \mathrm{C}$ per minute using the LightCycler 480 (Roche). During the heating process, fluorescence intensity was measured every $1^{\circ} \mathrm{C}$ (excitation at $465 \mathrm{~nm}$ and emission at $580 \mathrm{~nm}$ ).

\subsection{Circular dichroism}

Far UV Circular dichroism spectra were measured using a JASCO J-815 spectrometer at $20.0 \pm 0.2{ }^{\circ} \mathrm{C}$. Measurements were performed from 250 to $190 \mathrm{~nm}$ using $0.1 \mathrm{~nm}$ steps. The proteins were placed in a $0.1 \mathrm{~cm}$ path length quartz cuvette at concentrations of $2.8 \mu \mathrm{M}$ for $\mathrm{C} 28 \mathrm{~S} / \mathrm{C} 165 \mathrm{~S}$ in TRIS $10 \quad \mathrm{mM} \quad \mathrm{pH} \quad 7 \quad$ buffer or $10 \quad \mu \mathrm{M}$ for C60Y/C165H/L292C/M307C/G291STOP/native in $10 \mathrm{mM}$ sodium phosphate buffer at $\mathrm{pH} 7.5$. A buffer correction was then applied on signals. The spectra were averaged from 3 to 5 accumulations and corrected from buffer signal. Mean ellipticity values per residue $\left([\theta]_{\mathrm{mrw}, \lambda}\right)$ were calculated as already described.[33] 


\subsection{Affinity for Fe(II) by fluorescence measurement}

Fluorescence measurements were performed at $25^{\circ} \mathrm{C}$ using a Horiba Jobin-Yvon Fluoromax-4 spectrometer. The excitation wavelength was $285 \mathrm{~nm}$ (1 nm excitation slit widths), and the emission wavelength was $345 \mathrm{~nm}$ (5 nm slit widths). The proteins were placed at $0.65 \mu \mathrm{M}$ in 25 mM HEPES buffer set at pH 7.2 and the fluorescence changes were monitored upon titration with freshly prepared concentrated stock solutions of $\mathrm{Fe}\left(\mathrm{SO}_{4}\right)_{2}\left(\mathrm{NH}_{4}\right)_{2} \cdot 6 \mathrm{H}_{2} \mathrm{O}$. Fluorescence changes were analyzed by curve fitting (GraphPad Prism 6.0) according to the following equation (Eq. 2), where $E_{\mathrm{T}}$ is the enzyme concentration, $L_{\mathrm{T}}$ is the iron concentration, $K_{d}$ is the dissociation constant and $\Delta \mathbf{I}_{\max }$ is the maximum fluorescence quenching at high cofactor concentration (infinite limit).

(Eq. 2) $\quad \frac{I_{0}-I}{I_{0}}=\frac{\Delta I_{\max }}{I_{0}} * \frac{\left(K_{d}+E_{T}+L_{T}\right)+\sqrt{\left(K_{d}+E_{T}+L_{T}\right)^{2}-4 E_{T} L_{T}}}{2 E_{T}}$

\subsection{Spin-labeling}

The apo-enzymes (native and mutated enzymes) obtained after purification were labeled with 3-Maleimido-2,2,5,5-tetramethyl-1-pyrrolidinyloxy (Sigma Aldrich) spin label or Proxyl (P). All experiments were performed in $50 \mathrm{mM}$ MOPS pH 7.5 and in ice bath. The proteins were first placed in the presence of 100 molar equivalents of DTT (protein concentration was below $250 \mu \mathrm{M}$ to avoid precipitation) and the mixture was incubated $30 \mathrm{~min}$ on ice. The excess of DTT was removed using a desalting PD-10 column (GE Healthcare). Then, four successive additions of 10 equivalents of spin label $\mathbf{P}$ to the enzyme were performed every 30 min using a concentrated stock solution of $\mathbf{P}$ (32 $\mathrm{mM}$ in acetonitrile). Excess of free spin label was removed using a second desalting PD-10 column. The fractions containing the labeled enzyme were pooled and concentrated using Vivaspin 2 (Sartorius), 10 kD MWCO.

\subsection{Mass spectrometry}


Global mass determination. Experiments were performed using a MALDI-ToF mass spectrometer Microflex II from Bruker Daltonics (Deutschland) in the range from 2000 to $20000 \mathrm{Da}$ and in a linear and positive mode. External mass calibration was performed using the Protein Calibrant I (Bruker Daltonics). Samples of 20 to 30 pmoles of ACCO (unlabeled and labeled) were prepared by dilution in $10 \mu \mathrm{L}$ of $0.1 \%$ trifluoroacetic acid (TFA) in water (v/v) before being spotted onto a MALDI Target plate $(1 \mu \mathrm{L})$ and addition of a saturated solution of matrix $\alpha$-cyano-4-hydroxycinnamic acid $(1 \mu \mathrm{L})$ in $70 \%$ acetonitrile in water, $0.1 \%$ TFA (v/v).

Trypsic digestion. Prior to digestion with trypsin, labeled and unlabeled samples were alkylated, or not, with Iodoacetamide. Samples of 60 to 100 pmoles were digested by Trypsin at a ratio enzyme to substrate of $1 / 50(\mathrm{w} / \mathrm{w})$ (Sigma, St Louis, MO, USA) for 4 hours at $37^{\circ} \mathrm{C}$. The digested solutions were then acidified by $1 \mu \mathrm{L}$ of $12.5 \%$ trifluoroacetic acid (TFA) in water (v/v), vacuum dried before being spotted onto a MALDI Target plate $(1 \mu \mathrm{L})$ and addition of a saturated solution of matrix a-Cyano-4-hydroxycinnamic acid $(1 \mu \mathrm{L})$ of $70 \%$ acetonitrile in water, $0.1 \%$ TFA (v/v). Tryptic peptides were analyzed on the MALDI-ToF mass spectrometer Microflex II from Bruker Daltonics in the range from 600 to 5000 Da. Data acquisition was operated in positive and reflectron mode. External mass calibration was performed using the peptide calibration standard (Bruker Daltonics). A peak list was generated by a PMF (Peptide Mass Fingerprint) method from the FlexAnalysis software and manually checked. The experimentally measured peptide masses were compared with the theoretical tryptic peptides calculated from the sequence of ACCO, with variable modifications of the cysteine residues to take into account the number of grafted labels in the protein. In unlabeled samples, a $\mathrm{C}$ residue may be a free cysteine or a S-carbamidomethylcysteine (CAM-cys) if alkylated. In labeled samples, an unlabeled C residue may be as well a free cysteine (reduced form) or CAM ( MW 57.02). A grafted $\mathbf{P}$ can be detected as (i) S-proxyl-cysteine (Prox-cys, MW 237.12, -O form) 
(ii) S-proxyl-cysteine-H (Prox-cys-H, MW 238.13, OH form) (iii) S-proxyl-cysteine- $\mathrm{H}_{2} \mathrm{O}$ (Prox-cys- $\mathrm{H}_{2} \mathrm{O}$, MW 255.13) and (iv) S-proxyl-cysteine-plus $\mathrm{H}_{2} \mathrm{O}-\mathrm{H}$ (Prox-cys- $\mathrm{H}_{2} \mathrm{O}-\mathrm{H}, \mathrm{MW}$ 256.14). Consequently, the following mass increments were monitored throughout the set of experiments: (i) when starting material is a protein in its reduced form: 237.12 ( Prox-cys), 238.13 (Prox-cys-H), 255.13 (Prox-cys- $\mathrm{H}_{2} \mathrm{O}$ ), 256.14 (Prox-cys- $\left.\mathrm{H}_{2} \mathrm{O}-\mathrm{H}\right)$ and (ii) when starting material is alkylated with iodoacetamide: 180.10 (Prox-cys), 181.11 (Prox-cys-H), 198.11 (Prox-cys- $\left.\mathrm{H}_{2} \mathrm{O}\right), 199.12$ (Prox-cys- $\left.\mathrm{H}_{2} \mathrm{O}-\mathrm{H}\right)$.

\subsection{Cw-EPR}

Room temperature EPR spectra were recorded on an Elexsys E500II X-band spectrometer (Bruker) equipped with Elexsys Super High Q Sensitivity resonator operating at X-band (9.9 $\mathrm{GHz}$ ). The power of the microwave was $10 \mathrm{~mW}$, the magnetic field modulation amplitude was $0.1 \mathrm{mT}$ to avoid over-modulation of the signal and the frequency modulation was $100 \mathrm{kHz}$. The spin concentration was obtained by measuring the double integral of EPR recorded under nonsaturating conditions and compared to a reference sample. The labeling yield was obtained by calculating the ratio between the spin concentration and the total protein concentration. Simulation of EPR spectra were performed using SimLabel, a MATLAB Graphical User Interface (GUI) that uses some functions of the EasySpin toolbox[34] and dedicated to multicomponent simulations of EPR spectra from SDSL-EPR experiments.[35]

\section{Results}

\subsection{Mutagenesis of the native cysteines}

Prior to mutagenesis studies, the protein sequence of seven ACCO from Solanum lycopersicum (Figure S1) and forty-one ACCO from other organisms were aligned. Alignment of the important motifs already identified in the literature was verified and corrected when necessary. 
These include the Fe(II) coordination residues and the RXS motif conserved in all 2oxogutarate (2OG) dependent dioxygenases and related enzymes, a family of non-heme Fe(II) enzymes related to ACCO.[36] From the alignments, it appears that C28 and C165 are strictly conserved among ACCO orthologs and paralogs whereas C133 is highly conserved and C60 is weakly conserved (Tables S3 and S4).

The different native cysteines were systematically replaced by several aminoacids displaying different physicochemical properties (polar, apolar, charged). The specific activities for the different variants in cell extracts are displayed in Figure 2.
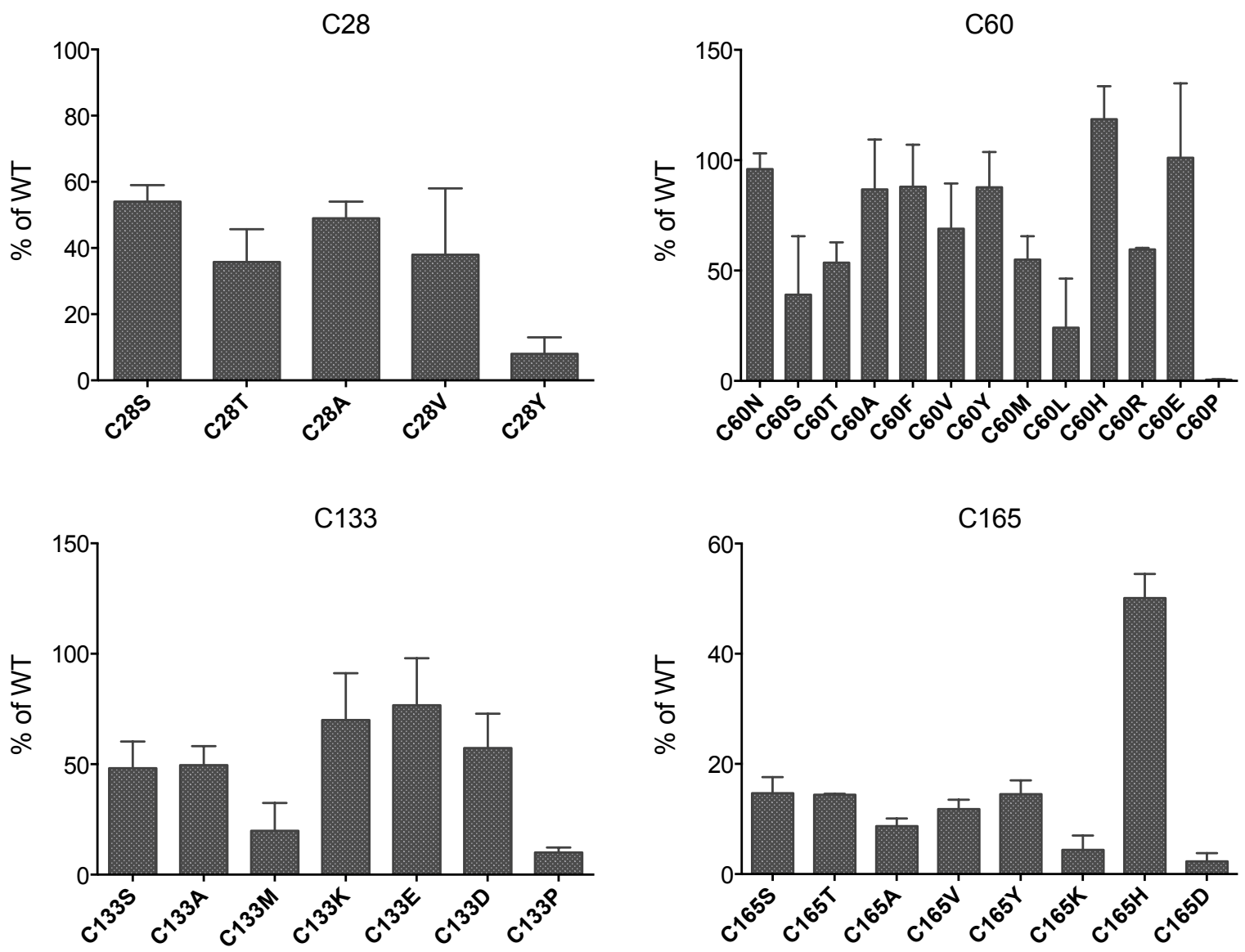

Figure 2. Effect of mutagenesis of the native cysteines of ACCO estimated from cell extracts. Specific activities (area of ethylene/ng of protein) are relative to that of the native enzyme. Ethylene production was measured by Gas Chromatography and ng of ACCO were estimated by ELISA assays. All variants were tested at least 3 times. 
Most of the tested C28X, and in particular C28S and C28A variants seem to retain significant activities (ca.35-50\%) with the exception of C28Y variant (only $11 \%$ of remaining activity). It has to be noted that these results have to be taken with care since the quantity of C28X enzymes in cells was found very low as compared to the native enzyme and that ethylene peaks were rather small (Table S5). In the case of the C165X, most of the variants retain little activity $(<15 \%$ as compared to the native enzyme) and the only variant that retains activity is $\mathrm{C} 165 \mathrm{H}$ variant ( $c a .50 \%$ of the native enzyme activity). In most cases, mutation of C60 by various aminoacids leads to significantly active enzymes. This is in agreement with the low conservation of this residue among ACCO sequences (Table S3 \& S4). Finally, mutations of C133 into serine (S) and alanine (A) lead to satisfyingly active enzymes (ca. 40-50\%). Mutations of C133 into aspartic or glutamic acids (D and E) or lysine (K) generate enzymes that retain more than $50 \%$ activity.

\subsection{Mutagenesis and deletion of the C-terminal part}

The C-terminal part includes residues after the helix $\alpha-10$, from $c a$. residue 290 (Figure 1). It has been proposed that K297 and R300 (tomato numbering) play a key role in the enzymatic activity, potentially participating to substrates and/or cofactor's binding.[10, 11] These two residues are conserved among ACCO enzymes. We generated a set of enzymes truncated at their C-terminus by incorporating a stop codon at different positions between G291 to S309 (the last amino acid of the protein labeled as G291STOP is A290). Specific activities were determined as described above and are displayed in Figure 3 (Table S6). From these data, it appears that truncated enzymes from G291 to F301 are completely inactive. Truncated enzymes after A306 (M307STOP and S309STOP) have also significantly reduced activities (ranging from $15-27 \%)$. 
Finally, we investigated the introduction of a cysteine at various positions on the C-terminal part starting from L292 residue. We obtained several fully active enzymes (Figure 3).
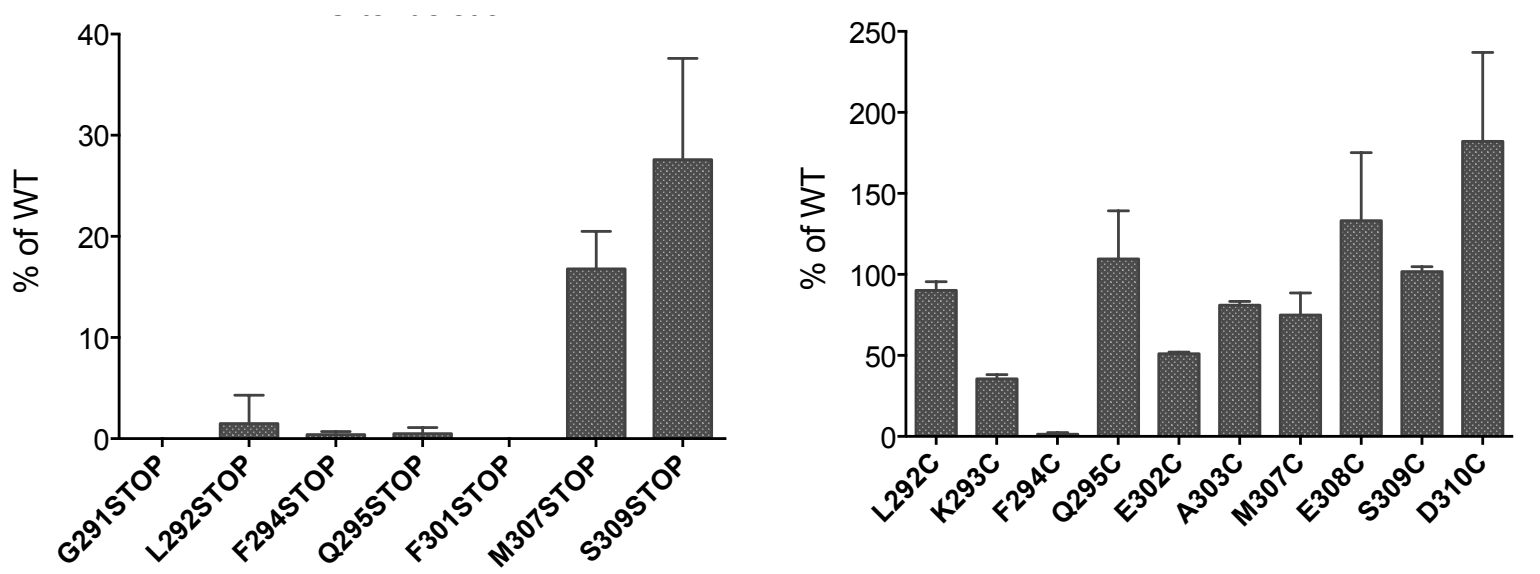

Figure 3. Effect of deletion of the C-terminal part (left) and insertion of a cysteine in C-terminal part (right) estimated from cell extracts. Specific activities (area of ethylene/ng of protein) are relative to that of the native enzyme. Ethylene production was measured by Gas Chromatography and ng of ACCO were estimated by ELISA assays. All variants were tested at least 3 times.

\subsection{Production characterization and activity of cysteine mutants}

At least one variant per native cysteine (C28, C60, C133 \& C165), one truncated enzyme (G291STOP) and two enzymes in which a cysteine was introduced in the C-terminal region (L292C \& M307C) were selected for further characterizations. The selected enzymes were produced and purified following procedures adapted from our already reported procedures.[11] It has to be noted that all enzymes were purified in the presence of EDTA. After purification, EDTA was removed and the enzymes were stored in their apo forms. Iron(II) was added prior to use at the specified concentration. Variants were characterized using different biochemical and biophysical techniques. 
Far UV Circular Dichroism (CD) spectroscopy confirmed that no major changes in the secondary structure content occurred in any of the variant studied (Figure S2). The CD spectra of all variants display minima at $208 \mathrm{~nm}$ and $222 \mathrm{~nm}$ typical of $\alpha$-helical secondary structure element contents. Even in the case of the G291STOP variant, the removal of $\alpha-11$ helix upon truncation of the C-terminal part after residue 290 does not lead to major modifications of the CD spectrum.

The thermal stability of the enzymes was estimated using a Thermal Shift Assay (TSA). Melting temperatures of selected enzymes are listed in Table S6. Tm of analyzed variants were found ranging between 52.5 and $54.5^{\circ} \mathrm{C}$ and are of the same order of magnitude than that of the native ACCO $\left(\mathrm{Tm}=53.5^{\circ} \mathrm{C}\right)$. The mutations therefore do not significantly affect the thermal stability of the enzymes.

Kinetic experiments performed on purified enzymes allowed to determine the MichaelisMenten parameters for several active variants. Reaction rates were measured at $29^{\circ} \mathrm{C}$ under initial velocity conditions while varying a single substrate in order to determine the kinetic constants of the substrates / cofactors of the reaction: ACC, ascorbate (ASC) and bicarbonate (BIC). The determined Michaelis-Menten parameters of the native and selected variants are reported in

Table 1. The apparent $\mathrm{K}_{\mathrm{m}}$ of the different variants for the different substrates/cofactors (ACC, bicarbonate or ascorbate) are roughly similar to those of the native enzyme and in the range of the parameters obtained with different ACCO enzymes. [32, 37-40] The relative $V_{\max }$ values are in relatively good agreement with the level of activity determined from cell extracts (data presented on Figure 2 \& Figure 3). There is however one notable difference: C28S that is predicted to retain $c a .50 \%$ of activity from cell extracts is poorly active after purification with $V_{\max }$ value more than 7 -folds lower (13\% of retained activity) as compared to that of the native 
ACCO. A similarly low activity has been previously reported for purified C28A from apple ACCO.[2] It has to be noted that, replacement of C28 by other aminoacids leads to a significant decrease in ACCO quantity in cell extracts (Table S2). Indeed, quantities found by ELISA assays range from $5-10 \%$ as compared to the native enzyme quantities, which is associated to very small ethylene peaks in gas chromatography. This situation may therefore affect the reliability of the estimated specific activities on cell extract and it is therefore possible that this situation leads to "false positive" data in our screening strategy.

Table 1. Apparent kinetic parameters for native ACCO and selected purified variants and dissociation constants for the $\mathrm{Fe}(\mathrm{II})$ cofactor determined by fluorescence quenching.

\begin{tabular}{|c|c|c|c|c|c|}
\hline & \multicolumn{4}{|c|}{ Kinetic parameters } & \multirow{3}{*}{$\begin{array}{c}\text { Kd Fe(II) } \\
(\mu \mathrm{M})\end{array}$} \\
\hline & \multicolumn{3}{|c|}{$\mathrm{K}_{\mathrm{M}}(\mathrm{mM})$} & \multirow{2}{*}{$\begin{array}{c}\mathrm{V}_{\max } \\
\left.(\mathrm{nmol} \cdot \min )^{-1}\right)\end{array}$} & \\
\hline & $\mathrm{ACC}$ & $\mathrm{BIC}$ & ASC & & \\
\hline Native & $0.18 \pm 0.04$ & $4.4 \pm 1.3$ & $3.1 \pm 0.7$ & $0.67 \pm 0.06$ & $3.5 \pm 0.9$ \\
\hline C28S & $0.24 \pm 0.04$ & $N D$ & $N D$ & $0.09 \pm 0.01$ & $N D$ \\
\hline C60Y & $0.16 \pm 0.04$ & $3.2 \pm 0.5$ & $2.7 \pm 0.8$ & $0.46 \pm 0.09$ & $2.9 \pm 0.9$ \\
\hline C165S & $N D$ & $N D$ & $N D$ & $N D$ & $2.1 \pm 0.3$ \\
\hline $\mathrm{C165H}$ & $0.34 \pm 0.06$ & $10.7 \pm 3.2$ & $1.9 \pm 0.3$ & $0.72 \pm 0.12$ & $3.5 \pm 0.9$ \\
\hline L292C & $0.33 \pm 0.06$ & $9.8 \pm 1.7$ & $2.8 \pm 0.4$ & $0.53 \pm 0.04$ & $3.3 \pm 0.3$ \\
\hline M307C & $0.20 \pm 0.04$ & $9.5 \pm 2.0$ & $3.0 \pm 0.7$ & $0.32 \pm 0.05$ & $7.3 \pm 0.4$ \\
\hline G291STOP & - & - & - & - & $3.7 \pm 0.3$ \\
\hline
\end{tabular}

ND: not determined

Finally, we investigated the binding of $\mathrm{Fe}(\mathrm{II})$ cofactor using tryptophan fluorescence quenching, a powerful technique to measure metal binding affinities.[41, 42] ACCO from tomato has three tryptophan residues and we have previously applied this technique to determine the binding affinity of various metal ions for two different ACCOs.[11, 32] Tryptophan emission $\left(\lambda_{\mathrm{cx}}=285 \mathrm{~nm} / \lambda_{\mathrm{cm}}=345 \mathrm{~nm}\right)$ is significantly quenched upon $\mathrm{Fe}(\mathrm{II})$ addition (up to 20-30\% decrease in intensity) with no change in the emission wavelength. Fluorescence intensities were recorded upon addition of increasing concentrations of freshly 
prepared Fe(II) stock solutions and the data were analyzed using equation 2 to determine the dissociation constants (

Table 1). For all analyzed enzymes, even for the C-terminal truncated G291STOP, binding of $\mathrm{Fe}(\mathrm{II})$ occurs with similar affinities (dissociation constants $\mathrm{K}_{\mathrm{d}}$ ranging from $c a$. 3-7 $\mu \mathrm{M}$ ). Mutation of the cysteine residues or removal of the C-terminal part does not alter the $\mathrm{Fe}(\mathrm{II})$ binding to the proteins and that even when inactive variants are obtained. In other words, the loss of activity in some of the variants is not correlated to a weaker iron binding.

\subsection{Spin labeling and characterization of labeled proteins}

Labeling experiments were conducted on native ACCO (4 cysteines available) and selected ACCO mutants. The proteins were labeled using a commercial nitroxide, Proxyl $(\mathbf{P})$, as presented in Scheme 2.

Scheme 2. Cysteine-labeling reaction with proxyl $(\mathbf{P})$

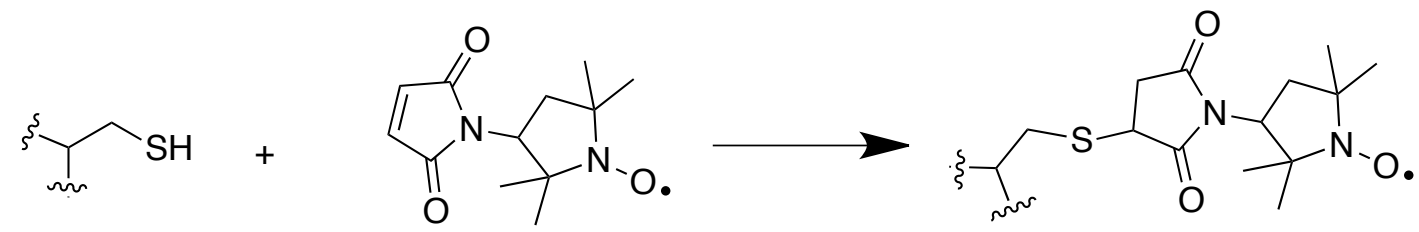

Cysteine residue

The labeled mutants were then analyzed by Mass Spectrometry (MS) to confirm the number of labels introduced per protein (global mass determination) and the labeling positions were determined by trypsic digestion and MALDI-Tof experiments (Table 2, Table S8). From the results, it appears that, in the case of the native enzyme, only the two cysteines C60 and C165 are accessible to the $\mathbf{P}$ label (the labeled native enzyme can be noted as $\mathrm{C} 60 * \mathrm{C} 165^{*}$ ). This is further confirmed by labeling experiments conducted on variants. Accordingly, the enzyme 
C60Y is only modified at $\mathrm{C} 165\left(\mathrm{C} 60 \mathrm{YC} 165^{*}\right)$ and the $\mathrm{C} 165 \mathrm{H}$ is only modified at $\mathrm{C} 60$ position $(\mathrm{C} 60 * \mathrm{C} 165 \mathrm{H})$. Therefore, with one single mutation, we were able to generate enzymes with a single cysteine accessible to covalent anchorage of $\mathbf{P}$. Finally, the cysteine introduced at positions 292 is accessible to the label and is found covalently modified by $\mathbf{P}$ using MS spectrometry. In the case of the cysteine introduced at position 307 (M307C), MS indicates that 3 labels have been introduced on the protein (Table S8). Trypsic digestion followed by MS analysis revealed that C60 and C165 are covalently modified and that C28 and C133 are not modified by the probe (consistent with all other labeling experiments). Therefore, although the peptide containing C307 could not be detected, it is highly probable that the introduced C307 on the C-terminal part is covalently modified by $\mathbf{P}$.

Table 2. Results of labeling experiments

\begin{tabular}{|c|c|c|c|c|}
\hline & $\begin{array}{c}\text { Number of } \\
\text { cysteines }\end{array}$ & $\begin{array}{c}\text { Number of labeled } \\
\text { cysteines }(M S)\end{array}$ & $\begin{array}{c}\text { Modified cysteines } \\
(M S)\end{array}$ & $\begin{array}{c}\text { Labeled enzyme } \\
\text { nomenclature }\end{array}$ \\
\hline Native & 4 & 2 & C60, C165 & $\mathrm{C} 60 * \mathrm{C} 165 *$ \\
\hline C60Y & 3 & 1 & C165 & С60YC165* \\
\hline $\mathrm{C165H}$ & 3 & 1 & C60 & $\mathrm{C} 60 * \mathrm{C} 165 \mathrm{H}$ \\
\hline$L 292 C$ & 5 & 3 & $\mathrm{C} 60, \mathrm{C} 165, \mathrm{C} 292$ & $\mathrm{C} 60 * \mathrm{C} 165 * \mathrm{C} 292 *$ \\
\hline M307C & 5 & $3^{\S}$ & $\mathrm{C} 60, \mathrm{C} 165, \mathrm{C} 307$ & $\mathrm{C} 60 * \mathrm{C} 165 * \mathrm{C} 307 *$ \\
\hline G291STOP & 4 & 2 & C60, C165 & C60*C165*_STOP \\
\hline
\end{tabular}

${ }_{\S}$ some (minor) di-modified enzyme has also been detected by MS

\subsection{Characterization of the labeled proteins}

Activity assays were performed on the labeled variants of ACCO (

Figure 4). The labeled native ACCO $\left(\mathrm{C} 60 * \mathrm{C} 165^{*}\right)$, displays very low activity $(<1 \%$ of the native enzyme before labeling). Using tryptophan fluorescence quenching experiments, we verified that the lack of activity of the labeled ACCO $\left(\mathrm{C} 60^{*} \mathrm{C} 165^{*}\right)$ was not due to loss of $\mathrm{Fe}(\mathrm{II})$ binding ability and the dissociation constant for Fe(II) binding for labeled and non-labeled were indeed found very similar $\left(\mathrm{K}_{\mathrm{d}}=3.5 \pm 0.9\right.$ and $3.8 \pm 0.6 \mu \mathrm{M}$ respectively $)$. In the case of labeling of $\mathrm{C} 60 \mathrm{Y}(\mathrm{C} 60 \mathrm{YC} 165 *)$ the remaining activity is again very low. However, almost no change 
in activity was observed in the case of $\mathrm{C} 165 \mathrm{H}\left(\mathrm{C} 60^{*} \mathrm{C} 165 \mathrm{H}\right)$. Dissociation constant for $\mathrm{Fe}(\mathrm{II})$ of the labeled $\mathrm{C} 165 \mathrm{H}(\mathrm{C} 60 * \mathrm{C} 165 \mathrm{H})$ was determined by fluorescence quenching measurements and was found to be very close to that of the unlabeled $\mathrm{C} 165 \mathrm{H}$ enzyme $(\mathrm{Kd}=2.1 \pm 0.3 \mu \mathrm{M})$. From these results, it appears that bioconjugation by $\mathbf{P}$ at $\mathrm{C} 165$ is deleterious to the enzyme function, which can also explain the absence of activity of the labeled $\mathrm{L} 292 \mathrm{C}\left(\mathrm{C} 60 * \mathrm{C} 165^{*} \mathrm{C} 292^{*}\right)$ and M307C (C60*C165*C307*), enzymes in which C165 is covalently modified by $\mathbf{P}$.

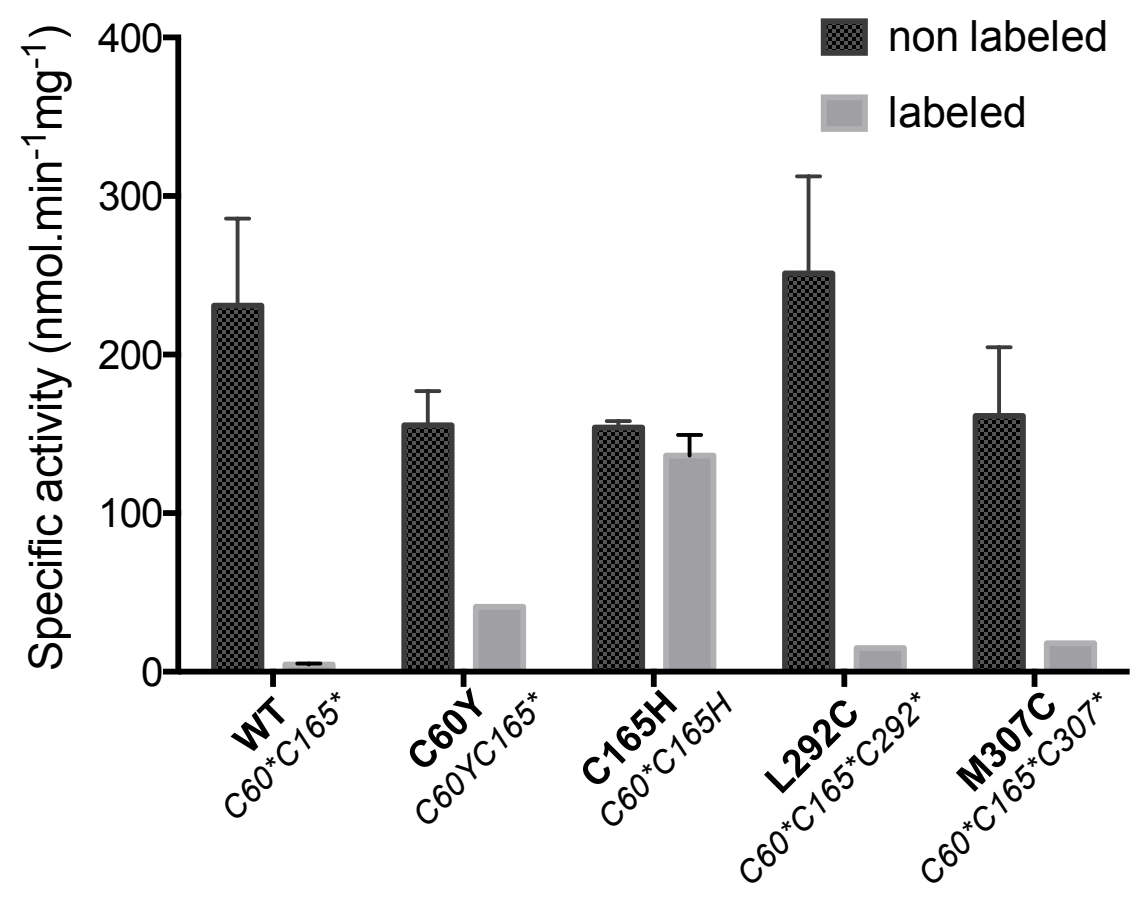

Figure 4. Specific activities (nmol of ethylene/ng of protein) of the different proteins and variants measured before and after labeling with $\mathbf{P}$.

\subsection{Continuous-wave (cw) EPR studies}

When grafted on proteins, nitroxide spin labels display EPR spectra whose shape reflects the spin label mobility that is related to local environmental constraints as well as global motional tumbling of the protein [19]. Simulation of the EPR spectral shapes allows determining the dynamic parameter $\tau_{\mathrm{c}}$ (i.e. the isotropic rotational correlation time) characteristics of the 
mobility of the probe.[35] The spectrum obtained using the labeled native ACCO $(\mathrm{C} 60 * \mathrm{C} 165 *)$ is displayed in Figure 5A. The spectrum is composite and can be simulated using two main components (Figure S3 \& Table S9). The first component (named "slow" component or comp1) has a a rotational correlation time $\tau_{\mathrm{c}}$ of $10.1 \mathrm{~ns}$ and the second (named "fast" component or comp2) has $\tau_{\mathrm{c}}$ of $2.9 \mathrm{~ns}$, each accounting for $65-68 \%$ and $33-35 \%$ of the signal intensity respectively. The spectra were identical when recorded in the absence (apo) or in the presence (holo) of iron cofactor (data not shown). EPR spectrum of labeled G291STOP $(\mathrm{C} 60 * \mathrm{C} 165 *$ STOP) was found very similar to that of the native $(\mathrm{C} 60 * \mathrm{C} 165 *)$ enzyme (Figure S4), confirming that the local structure of this construct at position C60 and C165 is not modified by the lack of the C-terminal part. $\mathrm{Cw}$ EPR spectra of the labeled mutants $\mathrm{C} 165 \mathrm{H}$ $(\mathrm{C} 60 * \mathrm{C} 165 \mathrm{H})$ and $\mathrm{C} 60 \mathrm{Y}\left(\mathrm{C} 60 \mathrm{YC} 165^{*}\right)$ were also recorded and were found very similar (Figure 5B and 5C). It is interesting to note that, although displaying a sole modification site, the spectra are complex and display several components. This may reflect either $(i)$ the presence of different conformations of the enzyme or (ii) more likely, the presence of rotameric states that the label can experience as already reported in the literature $[43,44]$.

In the case of $\mathrm{C} 165 \mathrm{H}$ enzyme $(\mathrm{C} 60 * \mathrm{C} 165 \mathrm{H})$, the labeled enzyme being active for ethylene production, we investigated the effect of substrate's or cofactors addition on the holo-enzyme and no spectral modification could be measured (data not shown). This is consistent with the fact that no significant structural changes are expected on the enzyme's core upon substrates binding (The $\mathbf{P}$ label being located on C60). Finally EPR spectra of the other labeled variants L292C and M307C were also recorded (Figure SI4) but, as the labeling targeted three cysteines, we didn't go further in the analyses due to the complexity of the multi-components EPR spectra. 


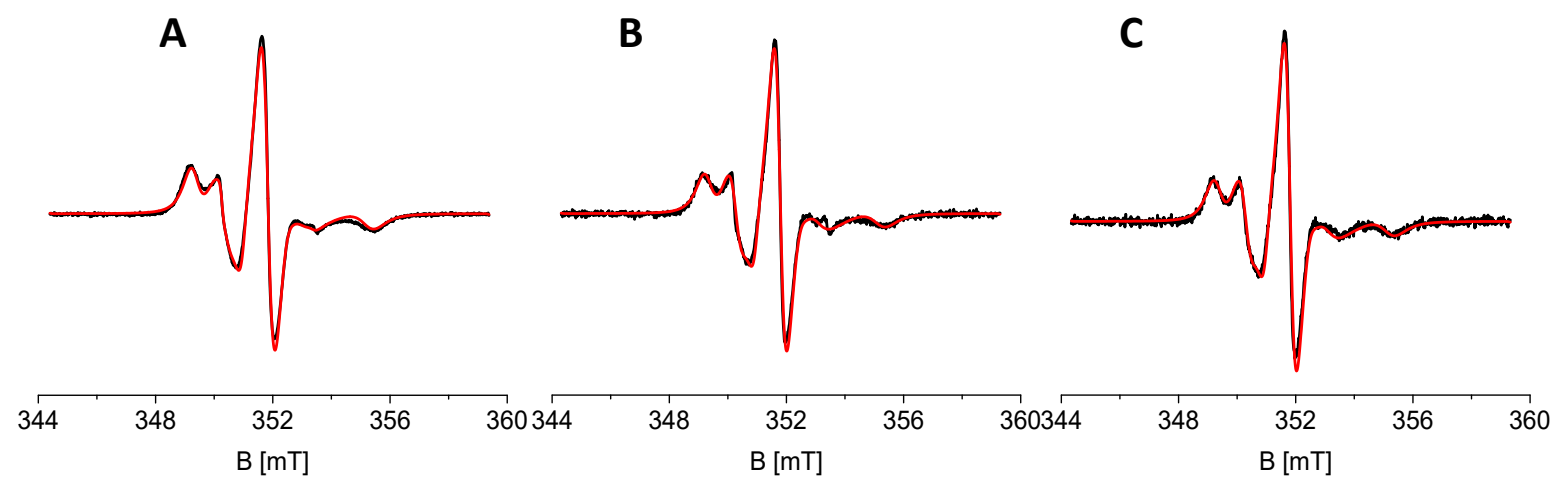

Figure 5. Room temperature cw EPR spectra (black) and simulated spectra (red) of A) native $\left.\left(\mathrm{C} 60 * \mathrm{C} 165^{*}\right) \mathrm{B}\right) \mathrm{C} 165 \mathrm{H}(\mathrm{C} 60 * \mathrm{C} 165 \mathrm{H})$ and C) C60Y (C60YC165*).

\section{Discussion}

Being the most robustly nucleophilic of the 20 canonical amino acids, cysteine residues are recognized as the most convenient targets for selective chemical modification of proteins. [24] Thanks to its relatively low abundance, protein constructs with a controlled number of cysteines are commonly obtained by conventional site-directed mutagenesis. A prerequisite to chemical modification is however to ensure that either the removal of natural cysteines or the introduction of new ones does not impair the function of the protein of interest.

ACCO from tomato (leACO1 / pTom13) contains 4 native cysteine residues: $\mathrm{C} 28, \mathrm{C} 60, \mathrm{C} 133$ \& $\mathrm{C} 165$, that could be used as anchoring residues for chemical modification of ACCO. In the literature, the role of the cysteines and the effect of their mutation on ACCO activity has not been extensively discussed since these cysteines are not involved in disulfide bridges and have no reported role in the catalytic activity. With the aim of providing a tool for cysteine chemical labeling and structural studies, we have generated various variants of the four native cysteines of tomato ACCO to reduce the amount of labeling sites of the protein. In a first instance, we screened variants for both quantity of ACCO produced (ELISA assay) and activity (ethylene detection by gas chromatography) in cell extracts (Figure 2), a screening strategy that can be 
extended to other variants of ACCO. Among variants further characterized several replacements for $\mathrm{C} 60, \mathrm{C} 133$ and $\mathrm{C} 165$ display biochemical and biophysical properties similar to the native enzyme properties (except for $\mathrm{C} 28$ which replacement may be hazardous since purified mutants display very low activity as already observed).[2]. This validates the individual replacement of these existing cysteines in a future chemical labeling strategy.

In order to follow C-terminal part dynamics of the enzyme, it is highly desirable to generate active variants bearing one probe (anchored on one cysteine) on this part of the enzyme. Therefore, to determine which minimal length of the C-terminal part is required to maintain activity, we generated truncated enzymes by incorporating a STOP codon at selected positions in a window ranging from 291 to 309. Enzymes truncated before F301 are completely inactive (Figure 3). This is coherent with previous reports on point mutations at K297, R300 or F301 (tomato numbering) in apple ACCO.[2, 10] The variants substituted with neutral or reversecharged residue (K297E \& R300E) had very low activities $(<1.5 \%)$ although K297R and R300K variants were shown to retain up to $30 \%$ activity. The two positively charged lysine and arginine residues are thus essential to the activity of ACCO and they have been proposed to be involved in bicarbonate and/or ascorbate binding.[10, 11] It therefore seems logical that our truncated variants that lack these aminoacids are inactive. Our truncated enzymes after residue 306 (M307STOP and S309STOP) have also significantly reduced activities $(<25 \%)$. Thus, removing as less as the last six residues in ACCO sequence is deleterious to the activity at least in SlACO1. Zhang et al. have previously mentioned that truncations of tomato ACCO after positions 302 or 304 lead to enzymes with significantly reduced activities $(<1$ and 5\% respectively).[8] Analyzed together, crystallographic data and deletion studies support a combined structural and functional role of this part of the enzyme. 
Finally, we verified that introduction of a cysteine is possible at various positions of the Cterminal part. The two variants we selected for further characterization (L292C \& M307C) display biophysical and biochemical properties similar to that of the native enzyme, supporting the fact that these positions are suitable ones for anchoring a probe.

To evaluate the effect of chemical modification on the properties and activity of ACCO we have used a nitroxide spin label containing a maleimide function $(\mathbf{P})$ that specifically reacts with cysteine nucleophiles (Scheme 2).[26, 28] MS analysis of the bioconjugate obtained with the native enzyme have revealed that only two cysteines are accessible to P: C60 and C165 (Table 2). From the different reported crystallographic structures, $[8,9]$ it appears that $C 28$ and C133 are rather buried, in agreement with the fact that they are poorly accessible to the label. Therefore, with a single point-mutation, either at C60 or C165, we generated enzymes that bear only one spin label on the protein's core. For yet not understood reasons, labeling of C165 with $\mathbf{P}$ leads to drastic drop of activity (C60YC165* in

Figure 4). On the contrary, covalent attachment of $\mathbf{P}$ on $\mathrm{C} 60(\mathrm{C} 60 * \mathrm{C} 165 \mathrm{H})$ generated a bioconjugate that retains significant activity and that is a good candidate for further functional and structural studies.

Room-temperature cw EPR spectra obtained with the different enzymes are composite and display two main components. They are characteristic of labels of restricted mobilities arising from their micro-environments. [19] The presence of several components, even in the case of mutants bearing a single nitroxide label $(\mathrm{C} 60 \mathrm{YC} 165 * \& \mathrm{C} 60 * \mathrm{C} 165 \mathrm{H})$ possibly arises from two different rotameric states of the spin labels rather than two different environments encountered by each individual spin label, as already reported in the literature $[43,44]$. In order to get further insight into the conformation of the C-terminal part, it is therefore necessary to use advanced 
techniques, e.g. pulsed EPR techniques such as DEER sequence that allows determining interspin distances in the range of $1.8-8.0 \mathrm{~nm}[45,46]$. This method requires the introduction of two strategically located spin labels within the protein. In the case of ACCO, introduction of a label on the C-terminal part of the enzyme is therefore an essential tool towards distance measurements and conformational studies.

In this context, we investigated the labeling of $\mathrm{L} 292 \mathrm{C} \& \mathrm{M} 307 \mathrm{C}$ variants with $\mathbf{P}$ and successfully obtained enzymes modified on the C-terminal part, $\mathrm{C} 60^{*} \mathrm{C} 165^{*} \mathrm{C} 292^{*}$ and $\mathrm{C} 60^{*} \mathrm{C} 165^{*} \mathrm{C} 307^{*}$, that are unfortunately inactive (Table 2 and

Figure 4). This lack of activity is most probably due to the fact that the labeled L292C and M307C enzymes bear 3 probes and in particular one on C165 that leads to a drop of activity. In order to see whether introduction of $\mathbf{P}$ on 292 or 307 positions is possible, we have generated double mutants C165HL292C \& C165HM307C, and both enzymes were found to keep significant activity after labeling with $\mathbf{P}(\mathrm{C} 60 * \mathrm{C} 165 \mathrm{HC} 292 *$ and $\mathrm{C} 60 * \mathrm{C} 165 \mathrm{HC} 307 *)$.[47] Advanced EPR analyses on such labeled variants are currently on-going in our laboratory.

\section{Conclusion}

In this article we have used a combination of mutagenesis, protein chemical modification, biochemical and biophysical studies to evaluate the effect of cysteine mutation and bioconjugation on ACCO properties and activity. Our results validate the individual replacement of three existing cysteines for future chemical labeling strategy (C60, C133, C165). On the contrary, among the four cysteines, replacement of C28 might be problematic. However, the orientation of the side-chain of this cysteine towards the inside of the protein makes it poorly accessible to bulky labels, as $\mathbf{P}$ label used in the present study. Indeed, MS experiments on the bioconjugates showed that only two cysteines over the four native ones are accessible to the label (C60 and $\mathrm{C} 165)$ and therefore, with a single mutation $(\mathrm{C} 60 \mathrm{Y}$ or $\mathrm{C} 165 \mathrm{H})$ we were able to 
provide enzymes bearing only one accessible cysteine and consequently only one label after chemical modification $\left(\mathrm{C} 60 \mathrm{YC} 165^{*} \& \mathrm{C} 60^{*} \mathrm{C} 165 \mathrm{H}\right)$. We also verified that introduction of a cysteine is possible at various positions of the C-terminal part (eg. L292C, M307C) paving the way towards an in-depth structure-function relationships study of the C-terminal part of ACCO. $\mathrm{Cw}$ EPR spectra were found complex, even when only one label is present on the enzyme. Work is in progress in our laboratory to investigate this complex enzymatic system using pulsed EPR techniques, therefore taking advantage of the above-mentioned mutagenesis work to anchor two labels on the protein, allowing distance measurements for conformational and dynamics studies.

Funding information. This work was supported by $A^{*}$ MIDEX project $\left(n^{\circ}\right.$ ANR-11-IDEX0001-02) funded by the « Investissements d'Avenir » French Government program, managed by the French National Research Agency (ANR). The authors are also grateful to the EPR facilities available at the national EPR network (IR CNRS 3443) and the Aix-Marseille Université EPR center. 


\section{References}

1. Bleecker, A. B., \& Kende, H. (2000). Ethylene: a gaseous signal molecule in plants. Annual review of cell and developmental biology, 16(1), 1-18. doi:10.1146/annurev.cellbio.16.1.1

2. Dilley, D. R., Wang, Z., Kadirjan-Kalbach, D. K., Ververidis, F., Beaudry, R., \& Padmanabhan, K. (2013). 1-Aminocyclopropane-1-carboxylic acid oxidase reaction mechanism and putative post-translational activities of the ACCO protein. AoB Plants, 5(0), plt031-plt031. doi:10.1093/aobpla/plt031

3. Simaan, A. J., \& Réglier, M. (2015). ACC Oxidase and Ethylene Biosynthesis in Plants. In R. P. Hausinger \& C. J. Schofield (Eds.), 2-Oxoglutarate-Dependent Oxygenases (Vol. 3, p. 425). Cambridge: Royal Society of Chemistry.

4. Kal, S., \& Que, L. (2017). Dioxygen activation by nonheme iron enzymes with the 2His-1-carboxylate facial triad that generate high-valent oxoiron oxidants. JBIC Journal of Biological Inorganic Chemistry, 22(2-3), 339-365. doi:10.1007/s00775-016-1431-2

5. Murphy, L. J., Robertson, K. N., Harroun, S. G., Brosseau, C. L., Werner-Zwanziger, U., Moilanen, J., et al. (2014). A Simple Complex on the Verge of Breakdown: Isolation of the Elusive Cyanoformate Ion. Science, 344(6179), 75-78. doi:10.1126/science. 1250808

6. Barlow, J. N., Zhang, Z., John, P., Baldwin, J. E., \& Schofield, C. J. (1997). Inactivation of 1-Aminocyclopropane-1-carboxylate Oxidase Involves Oxidative Modifications $\dagger$. Biochemistry, 36(12), 3563-3569. doi:10.1021/bi962521y

7. Mantri, M., Zhang, Z., McDonough, M. A., \& Schofield, C. J. (2012). Autocatalysed oxidative modifications to 2-oxoglutarate dependent oxygenases. The FEBS journal, 279(9), 1563-1575. doi:10.1111/j.1742-4658.2012.08496.x

8. Zhang, Z., Ren, J.-S., Clifton, I. J., \& Schofield, C. J. (2004). Crystal Structure and Mechanistic Implications of 1-Aminocyclopropane-1-Carboxylic Acid Oxidase-The Ethylene-Forming Enzyme. Chemistry \& biology, 11(10), 1383-1394. doi:10.1016/j.chembiol.2004.08.012

9. Sun, X., Li, Y., He, W., Ji, C., Xia, P., Wang, Y., et al. (2017). Pyrazinamide and derivatives block ethylene biosynthesis by inhibiting ACC oxidase. Nature communications, 8, 15758-14. doi:10.1038/ncomms 15758

10. Yoo, A., Seo, Y. S., Jung, J.-W., Sung, S.-K., Kim, W. T., Lee, W., \& Yang, D. R. (2006). Lys296 and Arg299 residues in the C-terminus of MD-ACO1 are essential for a 1-aminocyclopropane-1-carboxylate oxidase enzyme activity. Journal of Structural Biology, 156(3), 407-420. doi:10.1016/j.jsb.2006.08.012

11. Brisson, L., Bakkali-Taheri, N., Giorgi, M., Fadel, A., Kaizer, J., Réglier, M., et al. (2012). 1-Aminocyclopropane-1-carboxylic acid oxidase: insight into cofactor binding from experimental and theoretical studies. JBIC Journal of Biological Inorganic Chemistry, 17(6), 939-949. doi:10.1007/s00775-012-0910-3

12. Mizukami, S. (2011). Development of Molecular Imaging Tools to Investigate Protein Functions by Chemical Probe Design. Chemical \& Pharmaceutical Bulletin, 59(12), 1435-1446. doi:10.1248/cpb.59.1435

13. Hubbell, W. L., Cafiso, D. S., \& Altenbach, C. (2000). Identifying conformational changes with site-directed spin labeling. Nature Structural Biology, 7(9), 735-739. doi:10.1038/78956

14. Markwick, P. R. L., Malliavin, T., \& Nilges, M. (2008). Structural Biology by NMR: Structure, Dynamics, and Interactions. PLoS Computational Biology, 4(9), e1000168-7. doi:10.1371/journal.pcbi.1000168 
15. Albani, J. R. (2011). Structure and dynamics of macromolecules: absorption and fluorescence studies. doi:10.1016/b978-044451449-3/50008-3

16. Danielson, M. A., \& Falke, J. J. (1996). Use of 19F NMR to Probe Protein Structure and Conformational Changes. Annual review of biophysics and biomolecular structure, 25(1), 163-195. doi:10.1146/annurev.bb.25.060196.001115

17. Krall, N., da Cruz, F. P., Boutureira, O., \& Bernardes, G. J. L. (2015). Site-selective protein-modification chemistry for basic biology and drug development. Nature chemistry, 13(2), 168. doi:10.1038/nchem.2393

18. Mizukami, S., Hori, Y., \& Kikuchi, K. (2013). Small-Molecule-Based Protein-Labeling Technology in Live Cell Studies: Probe-Design Concepts and Applications. Accounts of Chemical Research, 47(1), 247-256. doi:10.1021/ar400135f

19. Martinho, M., Fournier, E., Le Breton, N., Mileo, E., \& Belle, V. (2018). Nitroxide spin labels: fabulous spy spins for biostructural EPR applications. In Electron Paramagnetic Resonance: Volume 26 (Vol. 26, pp. 66-88). Cambridge: Royal Society of Chemistry. doi:10.1039/9781788013888-00066

20. Haugland, M. M., Lovett, J. E., \& Anderson, E. A. (2017). Advances in the synthesis of nitroxide radicals for use in biomolecule spin labelling. Chemical Society Reviews, 113. doi:10.1039/C6CS00550K

21. Hubbell, W. L., López, C. J., Altenbach, C., \& Yang, Z. (2013). Technological advances in site-directed spin labeling of proteins. Current Opinion in Structural Biology, 23(5), 725-733. doi:10.1016/j.sbi.2013.06.008

22. Mchaourab, H. S., Steed, P. R., \& Kazmier, K. (2011). Toward the Fourth Dimension of Membrane Protein Structure: Insight into Dynamics from Spin-Labeling EPR Spectroscopy. Structure, 19(11), 1549-1561. doi:10.1016/j.str.2011.10.009

23. Bordignon, E., \& Bleicken, S. (2017). New limits of sensitivity of site-directed spin labeling electron paramagnetic resonance for membrane proteins. BBA - Biomembranes, 1-0. doi:10.1016/j.bbamem.2017.12.009

24. Boutureira, O., \& Bernardes, G. J. L. (2015). Advances in chemical protein modification. Chemical Reviews, 115(5), 2174-2195. doi:10.1021/cr500399p

25. Spicer, C. D., \& Davis, B. G. (2014). Selective chemical protein modification. Nature communications, 5, 4740. doi:10.1038/ncomms5740

26. Zheng, M., Zheng, L., Zhang, P., Li, J., \& Zhang, Y. (2015). Development of Bioorthogonal Reactions and Their Applications in Bioconjugation. Molecules, 20(2), 3190-3205. doi:10.3390/molecules20023190

27. Huang, Y., \& Liu, L. (2016). Protein modification: Standing out from the crowd. Nature chemistry, 8(2), 101-102. doi:10.1038/nchem.2443

28. Chalker, J. M., Bernardes, G. J. L., Lin, Y. A., \& Davis, B. G. (2009). Chemical Modification of Proteins at Cysteine: Opportunities in Chemistry and Biology. Chemistry - An Asian Journal, 4(5), 630-640. doi:10.1002/asia.200800427

29. HAMILTON, A. J., BOUZAYEN, M., \& Grierson, D. (1991). Identification of a tomato gene for the ethylene-forming enzyme by expression in yeast. Proceedings of the National Academy of Sciences, 88(16), 7434-7437. doi:10.1073/pnas.88.16.7434

30. Grierson, D., Hamilton, A. J., \& Lycett, G. W. (2012). The life and times of ACC oxidase, alias TOM13. Molecular Biology Reports, 40(4), 3021-3022. doi:10.1007/s11033-012-2375-4

31. Zhang, Z., Schofield, C. J., Baldwin, J. E., Thomas, P., \& John, P. (1995). Expression, purification and characterization of 1-aminocyclopropane-1-carboxylate oxidase from tomato in Escherichia coli. Biochemical Journal, 307(1), 77-85. doi:10.1042/bj3070077

32. Bakkali-Taheri, El, N., Tachon, S., Orio, M., Bertaina, S., Martinho, M., Robert, V., et al. (2017). Characterization of $\mathrm{Cu}$ (II)-reconstituted ACC Oxidase using experimental 
and theoretical approaches. Archives of Biochemistry and Biophysics, 623-624, 31-41. doi:10.1016/j.abb.2017.03.012

33. Kelly, S. M., Jess, T. J., \& Price, N. C. (2005). How to study proteins by circular dichroism. Biochimica et Biophysica Acta (BBA) - Proteins and Proteomics, 1751(2), 119-139. doi:10.1016/j.bbapap.2005.06.005

34. Stoll, S., \& Schweiger, A. (2006). EasySpin, a comprehensive software package for spectral simulation and analysis in EPR. Journal of magnetic resonance (San Diego, Calif. : 1997), 178(1), 42-55. doi:10.1016/j.jmr.2005.08.013

35. Etienne, E., Le Breton, N., Martinho, M., Mileo, E., \& Belle, V. (2017). SimLabel: a graphical user interface to simulate continuous wave EPR spectra from site-directed spin labeling experiments. Magnetic Resonance in Chemistry, 55(8), 714-719. doi: $10.1002 / \mathrm{mrc} .4578$

36. Clifton, I. J., McDonough, M. A., Ehrismann, D., Kershaw, N. J., Granatino, N., \& Schofield, C. J. (2006). Structural studies on 2-oxoglutarate oxygenases and related double-stranded $\beta$-helix fold proteins. Journal of Inorganic Biochemistry, 100(4), 644669. doi:10.1016/j.jinorgbio.2006.01.024

37. Dupille, E., Rombaldi, C., Lelièvre, J. M., Cleyet-Marel, J. C., Pech, J. C., \& Latché, A. (1993). Purification, properties and partial amino-acid sequence of 1aminocyclopropane-1-carboxylic acid oxidase from apple fruits. Planta, 190(1), 65-70.

38. Brunhuber, N. M. W., Mort, J. L., Christoffersen, R. E., \& Reich, N. O. (2000). SteadyState Kinetic Mechanism of Recombinant Avocado ACC Oxidase: Initial Velocity and Inhibitor Studies †. Biochemistry, 39(35), 10730-10738. doi:10.1021/bi0000162

39. Thrower, J. S., Blalock, R., \& Klinman, J. P. (2001). Steady-State Kinetics of Substrate Binding and Iron Release in Tomato ACC Oxidase †. Biochemistry, 40(32), 9717-9724. doi:10.1021/bi010329c

40. Dilley, D. R., Kadyrzhanova, D. K., \& Wang, Z. (2001). MECHANISM OF CARBON DIOXIDE ACTIVATION OF 1-AMINOCYCLOPROPANE-1-CARBOXYLATE (ACC) OXIDASE. Acta Horticulturae, (553), 143-144. doi:10.17660/ActaHortic.2001.553.27

41. Dunning Hotopp, J. C., Auchtung, T. A., Hogan, D. A., \& Hausinger, R. P. (2003). Intrinsic tryptophan fluorescence as a probe of metal and alpha-ketoglutarate binding to TfdA, a mononuclear non-heme iron dioxygenase. Journal of Inorganic Biochemistry, 93(1-2), 66-70. doi:10.1016/S0162-0134(02)00436-1

42. Straganz, G. D., Egger, S., Aquino, G., D’Auria, S., \& Nidetzky, B. (2006). Exploring the cupin-type metal-coordinating signature of acetylacetone dioxygenase Dke1 with site-directed mutagenesis: Catalytic reaction profile and Fe2+ binding stability of Glu$69 \rightarrow$ Gln mutant. Journal of Molecular Catalysis B: Enzymatic, 39(1-4), 171-178. doi:10.1016/j.molcatb.2006.01.019

43. Guo, Z., Cascio, D., Hideg, K., \& Hubbell, W. L. (2008). Structural determinants of nitroxide motion in spin-labeled proteins: Solvent-exposed sites in helix B of T4 lysozyme. Protein Science, 17(2), 228-239. doi:10.1110/ps.073174008

44. Guo, Z., Cascio, D., Hideg, K., Kálái, T., \& Hubbell, W. L. (2007). Structural determinants of nitroxide motion in spin-labeled proteins: Tertiary contact and solventinaccessible sites in helix G of T4 lysozyme. Protein Science, 16(6), 1069-1086. doi:10.1110/ps.062739107

45. Reginsson, G. W., \& Schiemann, O. (2011). Pulsed electron-electron double resonance: beyond nanometre distance measurements on biomacromolecules. Biochemical Journal, 434(3), 353-363. doi:10.1042/BJ20101871

46. Casey, T. M., \& Fanucci, G. E. (2015). Spin labeling and Double Electron-Electron Resonance (DEER) to Deconstruct Conformational Ensembles of HIV Protease. In 
Electron Paramagnetic Resonance Investigations of Biological Systems by Using Spin Labels, Spin Probes, and Intrinsic Metal Ions, Part B (Vol. 564, pp. 153-187). Elsevier. doi:10.1016/bs.mie.2015.07.019

47. Fournier, E., Tachon, S.; Belle, V., Simaan, A.J., Martinho, M., unpublished 